\title{
Local immune response to gastric Campylobacter in non-ulcer dyspepsia
}

\author{
JI WYATT,* BJ RATHBONE, $\ddagger$ RV HEATLEY† \\ From the Umivensity Departmentss of: "Pathology and $\dagger$ Medicine, St James's University Hospital, Leeds
}

SUMMARY Collomising Campyylobacter pyoloridis were identified histologically in gastric biopsy specimens from 89\% of 83, patiemts with mom-ullcer dyspepsia and chronic gastritis, but mot in 58 dyspeptic patients with mormal mucosa. The presence and popallation demsity of orgamismus was associatted with the presemce of imtracpithelivall mentrophills. In vivo coating of the organisms by hrost immumoglobullim was investigated by immumoperoxidase stainimg of IgA, IgG, and IgM in 54 biopsy specimems. IgA conted bacteria were seem in all cases of active gastritis, and in $60 \%$, of biopsy specinmems without imtraepitheliall meutirophints. Coating with IgG or IgM, or broth, was: correlated with activity of gastritis and wass rarelly seem in the absemce of a meutrophill imfiltrate.

Simce their recograitiom by Warrem amd Marsthall in $1983^{1}$ the presemce of collomisimg gastric campyylobacter litke organisums; offtem foumd im churomic gasturitis: has, been conffirmmed im maniny coummtries. ${ }^{2-4}$ The prevalemce of this bacteria, mow officiallity manmed Commpry

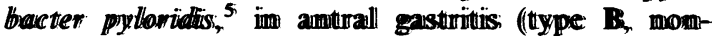
autoimmmume gastrititis) is comsistemtlly reported to be arroumed $90 \%$. The bacteria cam be growm in prare culture firom biopsy specimmens of the affected

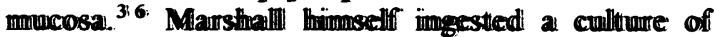
C pylloridiss amd developped symmptommattic gasturitiss, assorciatted with mucosall collonisattiom, thereby fullfilling Kocth's thiird and fourth postualates. ${ }^{7} C_{\text {pyllowidtis are }}$

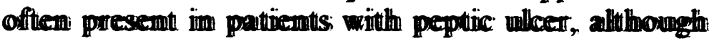
this association mayy be dure to comicurremt gasturitis, as most agemis, that heall ullcers, with the motable caceptiom of bismouth compoumds, do mot elimmimate either

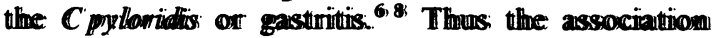

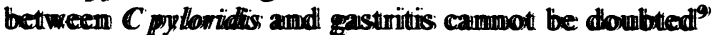
and must rivall that betweem momy other inffections diseases and theiri causative orgaunism.

The stomach is mormmally protected firom bacterriall imfectiom by its high louminall aciditity ${ }^{10}$ and a thick sunfiace coatimg of gastric mmucus." "Inmmumoglabuallim prodhucimg cells, whincth are sparse in the lammina propria of monmal gastiric murecosa, imcrease im mumblber im charomiic gastrititis." With the developpmemt of churomic gasturitis, the gasturic epiathetinum of the isthmmic zome sthows: secretion of IgA, together with lyssocymme,"

Acceptedi fior publication 6 Fetimuary 11996 and lactofierrim. ${ }^{14}$ These defiemces, imappropriate agaimst physicall or chemnicall imsults, would be well suited to combat a bacteriall pathogen. Evidence of a locall specific immume response to collonising C prollomidis wowld, therefore, favour a causative role for this orgaunism in chromic gasturitis.

We have previously showm amtii- $\mathbb{C}$ pylonidtis immunmoglobrallim in the servum amd gastic jurice of collomised patients. ${ }^{15}$ Oarr aim in the presemt sturdly was. to ianvestigeate the in vivo adkorptiom of thost immmu-

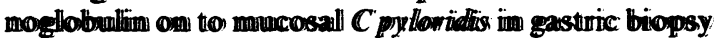
specimmems by the immmumohistochermicall dermomstratiom of amtibodly coatimg the bacteria.

\section{Marivill and methods.}

Paiured fiull thick mess emdloscopic biopsy specimbens of amitrall and bodly mucosal firomn 1411 patientsi with mon unlcer dyspepsia were sturdied. The presemce and severity of cthromic gastritisis was assessed by ome pathollogist (JW) om formallim fixsed paurafifim embedded $5 \mu \mathrm{mm}$ sectioms; staimed with havematioxyllim and eosim, accordimg to the criteria of Whitethead.." Collomising

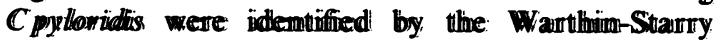
straim.

The disistribuntion of $\mathbb{C}$ pylloridisis and the presemce of IgG, IgA, and IgM coatuing the organisumsi were studtvied im detaill im 30) cases. In these biopsy specinmems; the mumbers of organnismms presemt in three sithes: the murcosail surfiace, the uppper, and the deep pontions; of the gastric pits, which were sepauratedy estimmatted om a

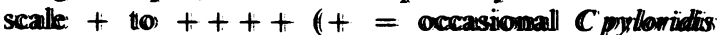

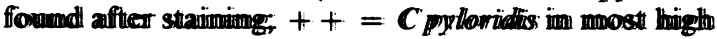




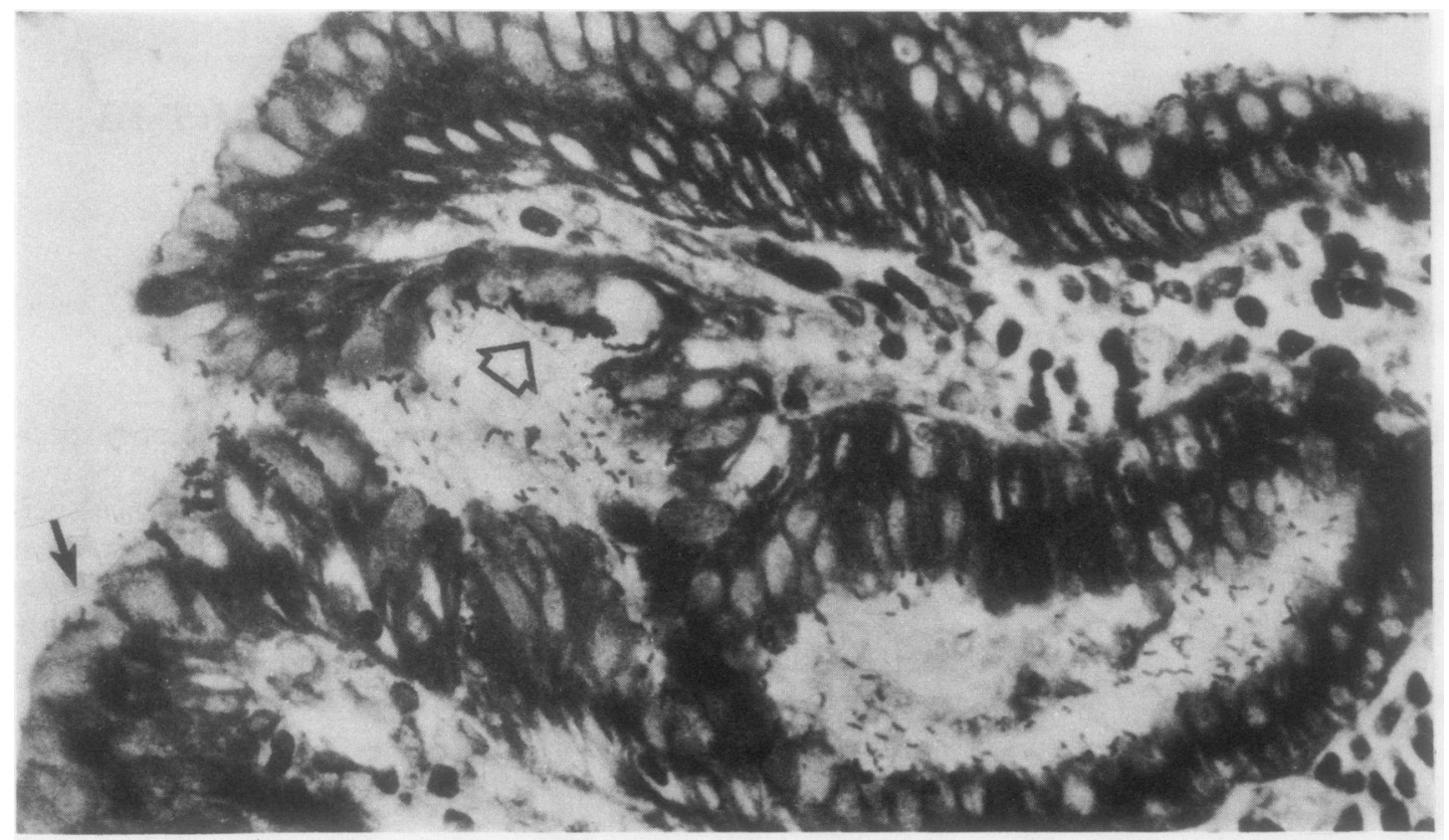

Fig. 1 Antral biopsy specimen stained by Warthin-Starry technique, showing colonising C pyloridis. Organisms are present on surface (arrow) and in upper and deep sections of pits. Both pits contain organisms, although of varying population density Dense colonies of bacteria (open arrow) present in upper pit (score $4+$ ). This specimen scored $9+$ for density of colonising Cpyloridis (surface $2+$; upper pits $4+$; deep pits $3+$ ). Original magnification $\times 130$.

power fields of surface and gastric pits; $+++=$ $C$ pyloridis in all high power fields of surface and pits; $+++=C$ pyloridis particularly numerous in all fields) (Fig. 1) and these values were added to quantify the density of bacterial colonisation, giving a possible range of 1 to $12+$.

Paired biopsy specimens were stained by the indirect immunoperoxidase method, with rabbit polyclonal antiserum to human IgA, IgM, and IgG (Dako) at a dilution of 1 in 500, haematoxylin being used as a counterstain. The presence of labelled $C$ pyloridis on the surface and in the upper and deep pits of each specimen was recorded. Negative controls consisted of sections of normal non-colonised mucosa, colonised mucosa with omission of rabbit antiserum, and sections from an adhesion study, in which $C$ pyloridis from broth culture adhered in vitro to normal antral mucosa maintained in tissue culture for two hours. All immunoperoxidase sections were examined without knowledge of the histological diagnosis and graded as follows: no immunoperoxidase labelling of bacteria present (-); one or two weakly positive bacteria present $( \pm)$; high incidence of weakly positive bacteria $(+)$; high incidence of strongly positive bacteria $(++)$.

Patterns of immunoperoxidase labelling of

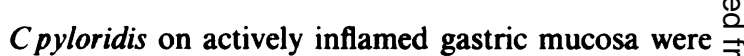
compared with those of normal body mucosa and 윽 mucosa from antrum and body showing inactive chronic gastritis (Figs. 2 and 3).

Statistical analysis was performed using the MannWhitney $\mathrm{U}$ test for comparing population densities of $\frac{\overline{0}}{0}$ Cpyloridis, and elsewhere by Fisher's exact test.

\section{Results}

Table 1 shows the prevalence of chronic gastritis and colonising $C$ pyloridis in one or both biopsy specimens $\rightarrow$ from 141 patients with non-ulcer dyspepsia. Cpyloridis were present in 74 of $83(89 \%)$ patients with chronic gastritis and in none of the 58 patients in -9 whom both antral and body mucosa were normal. $N$ Cpyloridis were detected on the morphologically normal body mucosa in 20 of 22 patients in whom $\sigma$ gastritis affected only the antrum. There was no cor- 0 relation between the severity of chronic gastritis (superficial or atrophic) and detection of Cpyloridis, $\stackrel{\oplus}{\rightarrow}$ except that organisms were never present on areas of $\bar{T}$ intestinal metaplasia. The association between the $O$ activity of gastritis and $C$ pyloridis on individual biop- $\stackrel{\square}{\square}$ sies was, however, significant (Table 2 ). In active gas- $\mathbb{\mathbb { Q }}$ tritis the neutrophils were predominantly between $\bar{\sigma}$ 

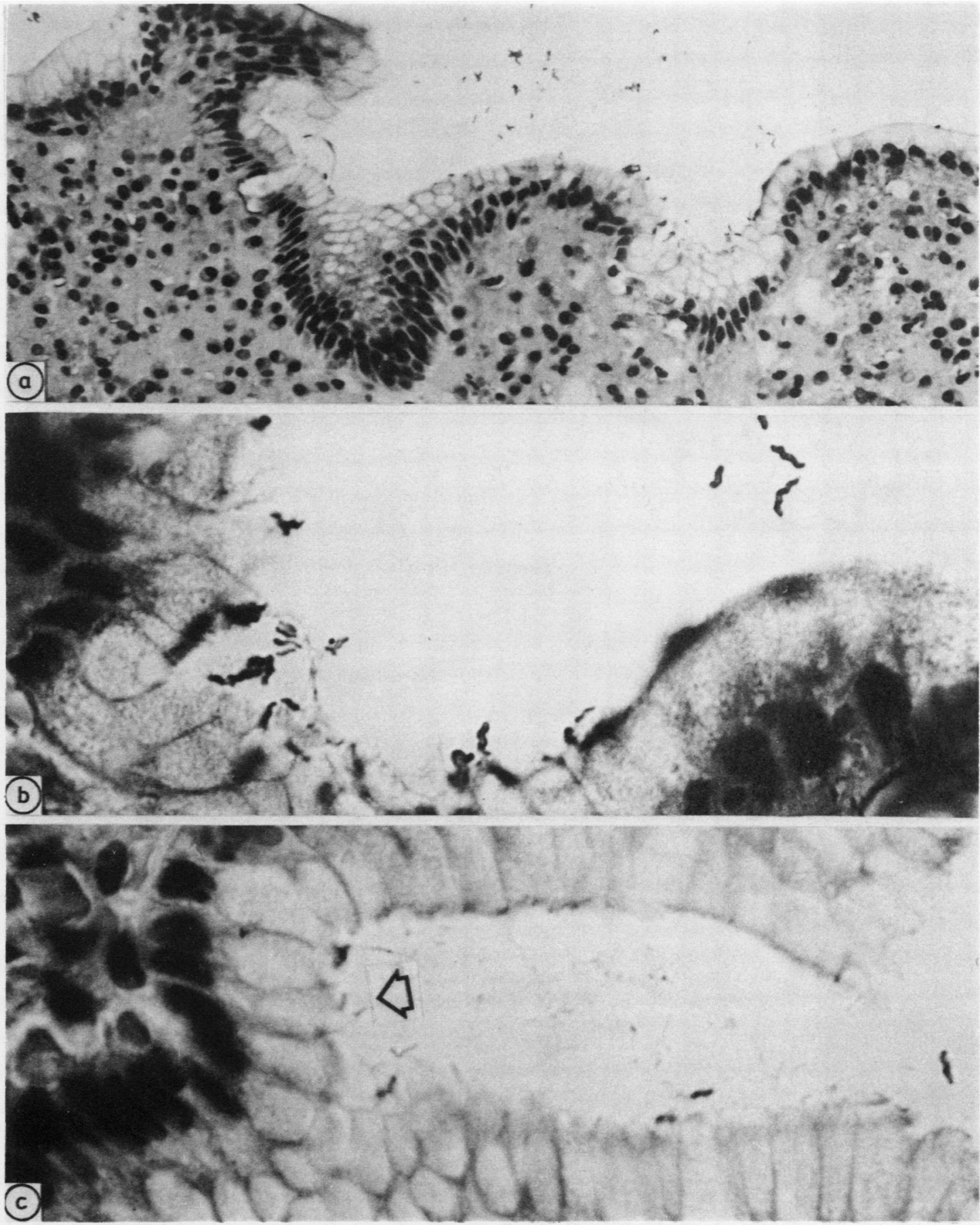

Fig. 2 Mucosal biopsy from gastric body stained by indirect immunoperoxidase technique for $1 g A$. (a) (b) Cpyloridis of characteristic morphology are present on and above surface; these score ++ for IgA labelling. (c) A gastric pit in same case; IgA positive $C$ pyloridis are present on surface and in upper pit; unlabelled organisms are present in deep pit (open arrow). Original magnification $(a) \times 80 ;(b)$ and $(c) \times 320$. 


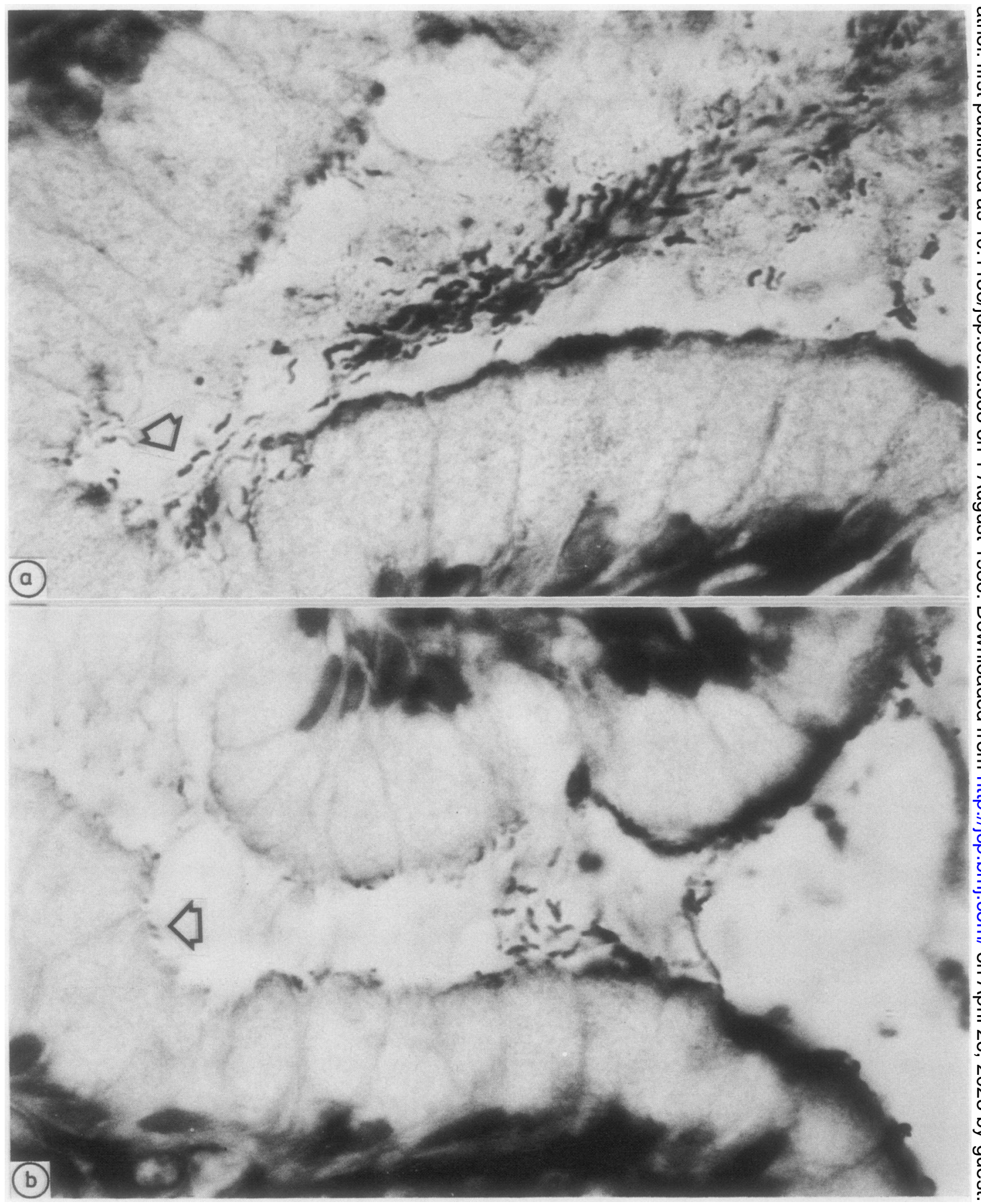

Fig. 3 Antral mucosa stained for IgA and IgG. (a) C pyloridis strongly positive for IgA $(++)$ are present on surface, while those in gastric pit are weakly positive $(+)$ (arrow). (b) IgG + + organisms are present on surface and IgG + in upper pit. Unlabelled C pyloridis are present in deeper part of pit (open arrow). Original magnification $\times 320$. 
Table 1 Prevalence of chronic gastritis and C pyloridis in 141 patients with non-ulcer dyspepsia

\begin{tabular}{|c|c|c|c|c|}
\hline Age & Total & $\begin{array}{l}\text { Normal gastric mucosa } \\
\text { Cpyloridis absent }\end{array}$ & $\begin{array}{l}\text { Chronic gastritis } \\
\text { Cpyloridis absent }\end{array}$ & $\begin{array}{l}\text { Chronic gastritis } \\
\text { Cpyloridis present }\end{array}$ \\
\hline $\begin{array}{l}\leqslant 20 \\
21-30 \\
31-40 \\
41-50 \\
51-60 \\
61-70 \\
71-80\end{array}$ & $\begin{array}{l}11 \\
29 \\
22 \\
24 \\
25 \\
20 \\
10\end{array}$ & $\begin{array}{r}6 \\
18 \\
13 \\
4 \\
12 \\
5 \\
0\end{array}$ & $\begin{array}{l}0 \\
1 \\
2 \\
1 \\
1 \\
2 \\
2\end{array}$ & $\begin{array}{r}5 \\
10 \\
7 \\
19 \\
12 \\
13 \\
8\end{array}$ \\
\hline
\end{tabular}

Table 2 Presence of $C$ pyloridis related to activity in 144 biopsy specimens showing chronic gastritis

\begin{tabular}{llll}
\hline Gastritis & \multicolumn{2}{l}{ Cpyloridis } & \\
\cline { 2 - 4 } & + & - & \\
\hline Active & 95 & 14 & p $<0.001$ \\
Inactive & 22 & 13 & 0 \\
\hline
\end{tabular}

epithelial cells rather than in the lumen of gastric glands (a pattern reminiscent of infective colitis ${ }^{16}$ ), and were most numerous in the deep portion of the pits.

Table 3 shows the histological diagnoses in the $\mathbf{3 0}$ pairs of biopsy specimens studied in detail. The specimens were of full thickness mucosa, with a mean number of 31.44 (SD 11.63) gastric pits per biopsy. The $\mathbf{3 0}$ cases included three with normal antral and body mucosae with no bacteria, included as negative controls. All of the remaining 54 biopsy specimens showed Cpyloridis colonisation; those of actively inflamed mucosa, however, carried a significantly greater population density of colonising bacteria than those showing inactive gastritis or normal mucosa $(p=0.0022)$ (Fig. 4).

Cpyloridis labelled by anti-IgA and anti-IgM were easily identified; background staining of gastric mucus in active gastritis occurred with anti-IgG, but labelled $C$ pyloridis could still be confidently detected. Unlabelled organisms were apparent due to their faint haematoxyphilia in areas of mucosa in which immunoperoxidase positive $C$ pyloridis were sparse or absent. The anti-Ig labelled $C$ pyloridis were always less numerous than those apparent on the WarthinStarry stain, suggesting that only a proportion of the organisms were coated by host immunoglobulin. In all sections examined immunoperoxidase negative Cpyloridis could be seen at the depths of the gastric pits.

The pattern of immunoperoxidase positivity of Cpyloridis for the three antibody classes in active gastritis was different to that in inactive gastritis and normal mucosa (Fig. 5). Numerous $C$ pyloridis, which were positive for IgG or IgM, or both, were present on the surface of 25 of 29 active gastritis biopsy specimens, but rarely seen on the others (6 of 25 , p < 0.001). IgA positive Cpyloridis were always present on the mucosal surface in active gastritis and were usually seen within pits. In the inactive and normal groups IgA positive $C$ pyloridis were found on the surface in $60 \%$ of cases, but were less commonly found within the gastric pits.

No immunoperoxidase stained organisms were seen on the three pairs of biopsy specimens from normal patients, or in the negative control slides. Sections from the adhesion study provided a useful negative control; $C$ pyloridis were also unstained by immunoperoxidase for IgA, IgG, and IgM.

\section{Discussion}

We propose that the immunoperoxidase labelling of mucosal $C$ pyloridis by anti-IgA, IgG, and IgM is due to the in vivo adsorption of specific host antibodies on to the bacteria. Other workers have used similar techniques to detect in vivo adsorbed antibody on oral bacteria $^{17}$ and on Legionella pneumophila. ${ }^{18}$ We have previously shown the presence of anti- $C$ pyloridis $\operatorname{IgA}$ and IgM in the gastric juice of colonised subjects. The characteristic morphology, position, and population density of $\boldsymbol{C}$ pyloridis on the mucosal surface in tissue sections $^{1}$ allowed the immunoperoxidase positive organisms to be identified with confidence. This posi-

Table 3 Histological diagnoses in 30 paired biopsy specimens for immunoperoxidase study

\begin{tabular}{llll}
\hline & $\begin{array}{l}\text { Active chronic } \\
\text { gastritis }\end{array}$ & $\begin{array}{l}\text { Inactive chronic } \\
\text { gastritis }\end{array}$ & $\begin{array}{l}\text { Normal (inchudes three } \\
\text { negative control cases) }\end{array}$ \\
\hline $\begin{array}{l}\text { Antral mucosa } \\
\text { Body mucosa }\end{array}$ & 22 & 5 & 3 \\
\hline
\end{tabular}




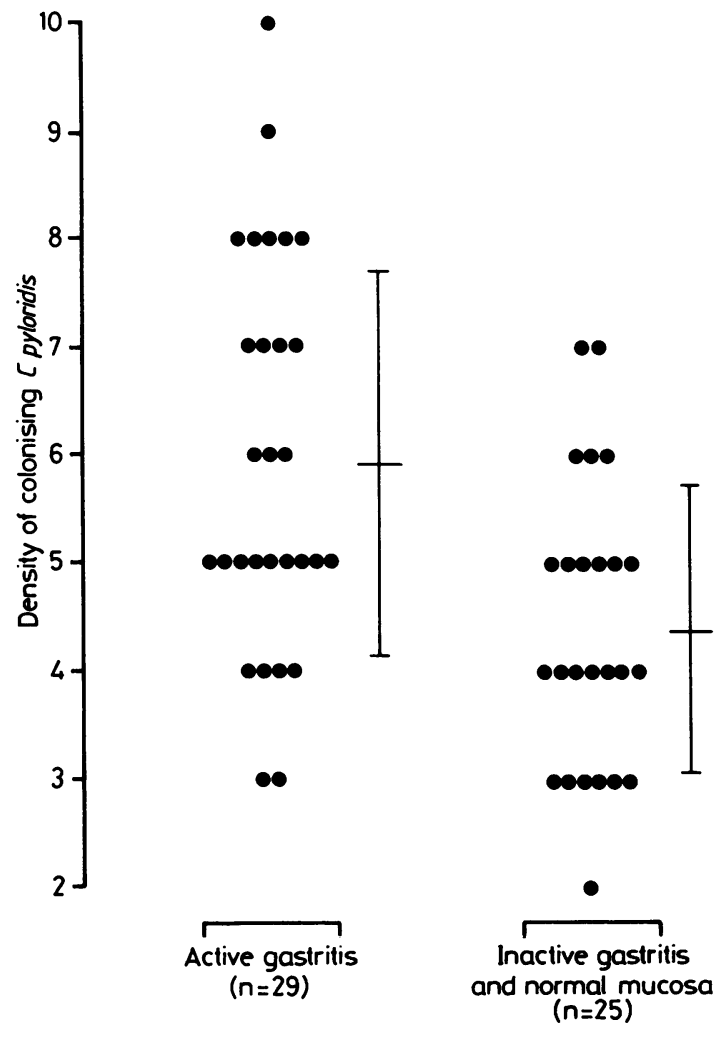

Fig. 4 Density of colonising Cpyloridis in biopsy specimens showing active gastritis compared with that of inactive gastritis and normal mucosa $(p=0.0022)$.

tivity is unlikely to be due to a non-specific cross reaction as some unlabelled $C$ pyloridis were also present in each section.

Lymphocytes and plasma cells are sparse in the lamina propria of the normal stomach, and an increase in their number is the principal criterion for the histological diagnosis of chronic gastritis. ${ }^{12}$ Interestingly, the intestinal mucosa of neonates and germ free animals is similarly devoid of mononuclear cells before contact with luminal antigens. ${ }^{19}$ The main class of antibody present in mucosal secretions is dimeric IgA, which is produced locally by plasma cells in the lamina propria and transported from the interstitium to the lumen by secretory component, a protein synthesised by the epithelial cells. ${ }^{20}$ This secretory mechanism, which is apparently inactive in the normal stomach, has been shown in inflamed gastric mucosa, together with the secretion of lysozyme ${ }^{13}$ and lactoferrin. ${ }^{14}$ The mucosal plasma cells throughout the gastrointestinal tract are predominantly of IgA class, ${ }^{19}$ although an increase in the IgG and IgM plasma cell population occurs during the active phase in various inflammatory condi

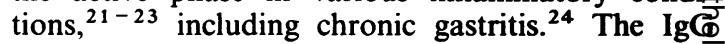
appears in secretions during active inflammation by means of a non-specific increase in transudation of serum proteins across the inflamed epithelium. ${ }^{25}$

We detected coating of $C$ pyloridis by host $\operatorname{IgA}$ i all cases with active gastritis and in many with inace tive gastritis, a finding in accordance with the preporo derance of $\operatorname{IgA}$ in mucosal secretions. IgA protecto the mucosa by interfering with the adhesion of organisms to the epithelial surface. ${ }^{26}$ It has als 8 recently been shown to be capable of inducing ant body dependent cell mediated activity against enterog pathogenic bacteria. ${ }^{27} \operatorname{IgA}$ does not, howeve $\overline{8}$ opsonise or fix complement and therefore does not enhance neutrophil phagocytosis of coate⿻्巳 organisms. This is in keeping with our observation ofo IgA coated $C$ pyloridis, irrespective of the presence o\& a neutrophil infiltrate in the mucosa. IgG and IgM coated $C$ pyloridis were observed almost exclusively on actively inflamed mucosae. Both these antibodies fix complement, with IgG also opsonising bacteriao thus both would be expected to enhance neutrophn activity against $C$ pyloridis. Other authors have observed phagocytosed $C$ pyloridis in neutrophils ong the mucosal surface. ${ }^{4}$ This association of active gastritis with the presence of IgM and IgG coated Cpyloridis is therefore corroborative evidence thas the inflammatory response may, indeed, be elicited b this organism.

The consistent observation of unlabelle $\$$ Cpyloridis deep in the gastric pits is of considerabl $\vec{F}$ interest. Although the self induced Campylobactes gastritis of Marshall resolved spontaneously by the fourteenth day, ${ }^{7}$ colonisation by organisms has been. shown to persist for at least four months in asympos tomatic subjects. ${ }^{28}$ Indeed, the prevalence of Cpyloridis in patients of all ages and with all grades of chronic gastritis suggests that colonisation, onc. established, may persist indefinitely. The host immune response is therefore not effective in eradicating the organism. In their ecological niche deep i⿱ the gastric pits, Cpyloridis may evade contact wit host immunoglobulin, at least in a concentration. sufficient to be detected by our immunoperoxidases technique. The alternative explanation for theit persistence-that $C$ pyloridis are merely commensa in the inflamed stomach-seems unlikely in view of the systemic antibody response in colonised subjects $^{215}$ and their association with activity of gas? tritis, an observation recently confirmed by electro microscopy. ${ }^{29}$

We do not yet know the clinical importance of Cpyloridis in the pathogenesis of chronic gastritis The immune mechanisms of the stomach are equipped to combat a luminal antigen, and the hist@ 

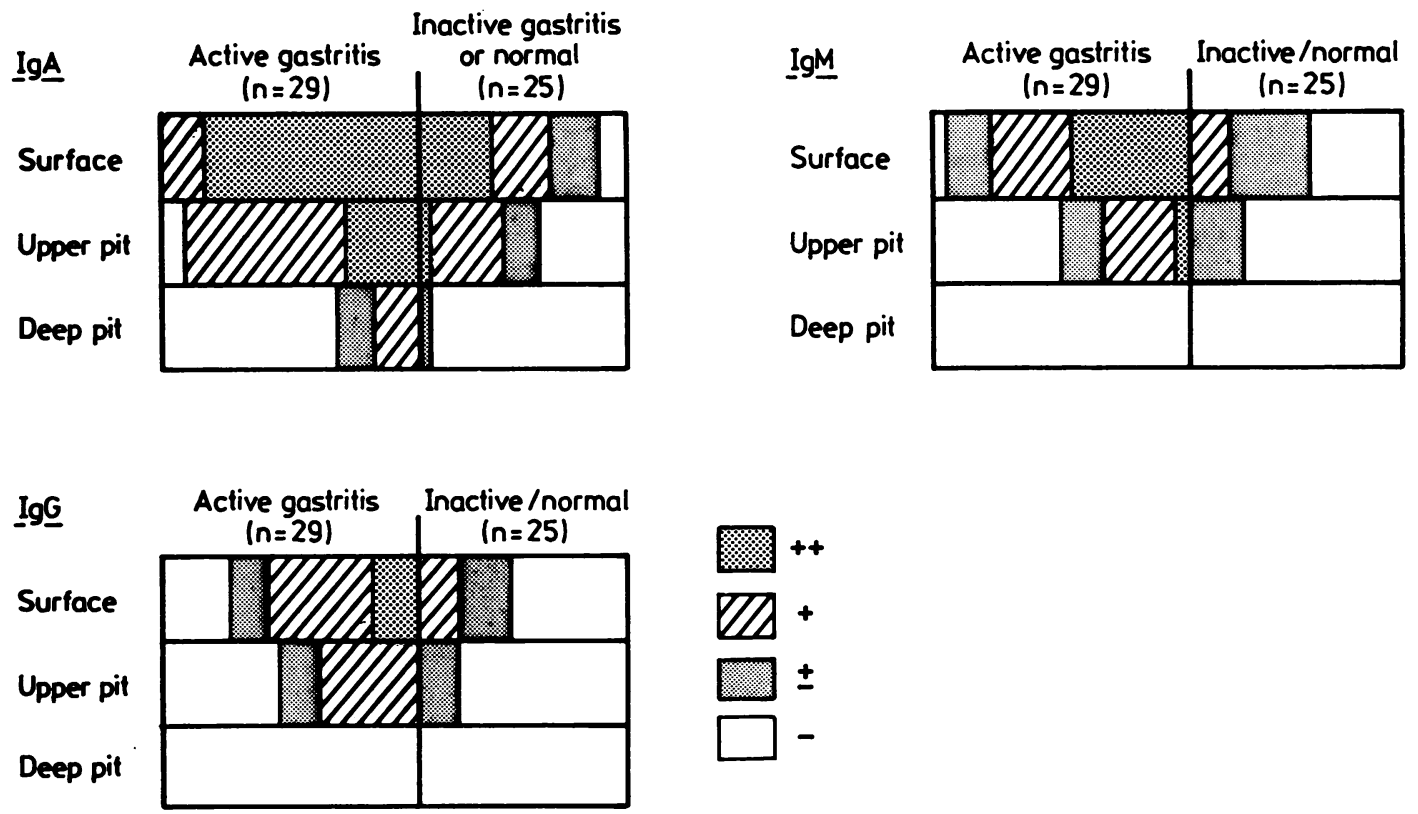

Fig. 5 Immunoperoxidase labelling of C pyloridis present on surface and in upper and deep gastric pits by anti-IgA, IgG, and IgM.

logical features of chronic gastritis are consistent with those of a response to chronic infection. We have presented evidence for the in vivo coating of Cpyloridis by host antibody, the class of which varies with the activity of the gastritis. A chronic infection by $C$ pyloridis, therefore, offers a plausible explanation for the histological and immunopathological features observed in type B chronic gastritis.

We thank Miss Sally Grey and Mr Declen Lunny for technical help, Dr MF Dixon for his helpful suggestions, and Mrs C Mann and Mrs J Fearnley for secretarial help.

\section{References}

${ }^{1}$ Warren JR, Marshall B. Unidentified curved bacilli on gastric epithelium in active chronic gastritis. Lancet 1983;i:1273-5.

2 Jones DM, Lessells AM, Eldridge J. Campylobacter-like organisms on the gastric mucosa: culture, histological and serological studies. J Clin Pathol 1984;37:1002-6.

${ }^{3}$ Langenberg ML, Tytgat GNJ, Schipper MEI, Reitra PJGM, Zanen HC. Campylobacter-like organisms in the stomach of patients and healthy individuals. Lancet 1984;i:1348.

${ }^{4}$ Lee WK, Gourley WK, Buck GE, Subramanyam K. A light and electron microscopic study of a campylobacter-like bacteria inhabiting the human stomach. Gastroenterology 1985;88:1470.

${ }^{5}$ Anonymous. Validation of the publication of new names and new combinations previously effectively published outside the IJSB. Int J Syst Bacteriol 1985;35:223-5.
${ }^{6}$ Marshall BJ, Warren JR. Unidentified curved bacilli in the stomach of patients with gastritis and peptic ulceration. Lancet 1984;i:1311-4.

${ }^{7}$ Marshall BJ, Armstrong JA, McGechie DB, Glancy RJ. Attempt to fulfil Koch's postulates for pyloric campylobacter. Med $J$ Aust 1985;142:436-9.

${ }^{8}$ Lambert JR, Hansky J, Davidson A, Pinkard K, Stockman K. Campylobacter-like organisms (CLO) - in vivo and in vitro susceptibility to antimicrobial and antiulcer therapy. Gastroenterology 1985;88:1462.

9 Thomas JM. Campylobacter-like organisms in gastritis. Lancet 1984;ii: 1217.

${ }^{10}$ Giannella RA, Broitman SA, Zamcheck N. Gastric acid barrier to ingested micro-organisms in man: studies in vivo and in vitro. Gut 1972;13:251-6.

${ }^{11}$ Gibbons RJ. Review and discussion of the role of mucus in mucosal defence. In: Strober W, Hanson LA, Sell KW, eds. Recent advances in mucosal immunity. New York: Raven Press, 1982:343-51.

${ }^{12}$ Whitehead R. Mucosal biopsy of the gastrointestinal tract. 3rd ed. Philadelphia: WB Saunders, 1984.

${ }^{13}$ Isaacson P. Immunoperoxidase study of the secretory immunoglobulin system and lysozyme in normal and diseased gastric mucosa. Gut 1982;23:578-88.

${ }^{14}$ Valnes K, Brandtzaeg P, Elgjo K, Stave R. Specific and nonspecific humoral defence factors in the epithelium of normal and inflamed gastric mucosa. Gastroenterology 1984;86:402-12.

${ }^{15}$ Rathbone BJ, Wyatt JI, Worsley BW, et al. Systemic and local antibody responses to gastric Campylobacter pyloridis in nonulcer dyspepsia. Gut 1986:27:642-7.

${ }^{16}$ Price AB, Day DW. Pseudomembranous and infective colitis. In Recent advances in histopathology. Vol 11. Edinburgh: Churchill Livingstone, 1981:99-117.

${ }^{17}$ Brandtzaeg P, Fjellanger I, Gjeruldsen ST. Adsorption of immunoglobulin $A$ on to oral bacteria in vivo. $J$ Bacteriol 1968 
96:242-9.

${ }^{18}$ Boyd JF, McWilliams E. Immunoperoxidase staining of Legionella pneumophila. Histopathology 1982;6:191-6.

19 Tomasi TB, Grey HM. Structure and function of immunoglobulin A. Progress in Allergy 1972;16:81-213.

${ }^{20}$ Solari R, Kraehenbuhl JP. The biosynthesis of secretory component and its role in the transepithelial transport of $\operatorname{IgA}$ dimer. Immunology Today 1985;6:17-20.

${ }^{21}$ Rosekrans PCM, Meijer CJLM, Van Der Wal AM, Cornelisse CJ, Lindeman J. Immunoglobulin containing cells in inflammatory bowel disease of the colon: a morphometric and immunohistochemical study. Gut 1980;21:941-7.

${ }^{22}$ Brandtzaeg $\mathbf{P}$, Baklien $\mathrm{K}$, Fausa $\mathrm{O}$, Hoel PS. Immunohistochemical characterisation of local immunoglobulin formation in ulcerative colitis. Gastroenterology 1974;66:1123-36.

${ }^{23}$ Keren DF, Appelman HD, Dobbins WO, et al. Correlation of histopathologic evidence of disease activity with the presence of immunoglobulin-containing cells in the colons of patients with inflammatory bowel disease. Hum Pathol 1984;15:757-63.

${ }^{24}$ Van Spreeuwel JP, Lindeman J, Van Maanen J, Meyer CJLM.
Increased numbers of IgE containing cells in gastric and duodenal biopsies. An expression of food allergy secondary to으 chronic inflammation? J Clin Pathol 1984;37:601-6.

25 Jonard PP, Rambaud JC, Dive C, Vaerman JP, Galian A, Delacroix DL. Secretion of immunoglobulins and plasma proteins from the jejunal mucosa. $J$ Clin Invest 1984;74:525-35.

${ }^{26}$ Williams RC, Gibbons RJ. Inhibition of bacterial adherence by secretory immunoglobulin A: a mechanism of antigen disposal. Science 1972;177:697-9.

${ }^{27}$ Tagliabue A, Boraschi D, Villa L, et al. IgA-dependent cell- $\stackrel{\mathbb{\complement}}{\varrho}$ mediated activity against enteropathogenic bacteria: distribution, specificity and characterisation of the effector cells. J Immunol 1984;133:988-92.

${ }^{28}$ Tytgat GNJ, Langenberg ML, Rauws E, Rietra PJGM. Campylobacter-like organisms in the human stomach. Gastro- $\vec{\omega}$ enterology 1985;88:1620.

${ }^{29} \mathrm{Steer} \mathrm{HW}$. The gastro-duodenal epithelium in peptic ulceration. $\mathrm{C}$ J Pathol 1985;146:355-62.

Requests for reprints to: Dr JI Wyatt, Department of Pathology, University of Leeds, Leeds LS2 9JT. 